\title{
Література:
}

1. Sarasvathy S. D., Kotha S. Eff ectuation in the Management of Knightian Uncertainty: Evidence from the Real Networks Case : Research on Management and Entrepreneurship/ J. Butler, series ed. Vol 1. Greenwich, CT: IAP Inc., 2001.

2. Dew N., Sarasvathy S. D. New Market Creation through Transformation : Journal of Evolutionary Economics. 2005.

3. Dew N., Sarasvathy S. D., Read S., Wiltbank R. Aff ordable Loss: Behavioral Economic Aspects of the Plunge // Strategic Entrepreneurship Journal. 2009b

4. Politis D., Winborg J., Dahlstrand A. L. Exploring the Resource Logic of Student Entrepreneurs: International Small Business Journal. 2012.

5. Harms R., Schiele H. Antecedents and Consequences of Eff ectuation and Causation in the International New Venture Creation Process: Journal of International Entrepreneurship. 2012.

6. Г. В. Широкова, А. К. Ласковая “Загально статегічний менеджемент”/ "Концепция эффектуации: этапы развития и основные направления исследований” 2015

7. Fisher E., Reuber A. R. Social Interaction via New Social Media: (How) Can Interactions on Twitter Affect Effectual Thinking and Behavior?: Journal of Business Venturing.2011.

8. Wiltbank R., Dew N., Read S., Sarasvathy S. D. What to Do Next? The Case for NonPredictive Strategy: Strategic Management Journal. 2006

UDK 331.524

JEL classification: E24

Melnychuk V.E. ORCID ID: 0000-0001-8246-4076

National Technical University of Ukraine "Igor Sikorsky Kyiv Polytechnic Institute"

\section{TRANSFORMATION OF THE ROLE OF HUMAN CAPITAL IN TERMS OF INFORMATION ECONOMY}

\section{ТРАНСФОРМАЦІЯ РОЛІ ЛЮДСЬКОГО КАПІТАЛУ В УМОВАХ ІНФОРМАЦІЙНОЇ ЕКОНОМІКИ}

This article examines the process of transforming the labor market and the role of human capital in it in connection with changes that take place in Ukraine and in the world. Increasing the amount of information led to the transformation of system processes, the movement of vectors in the recruitment of personnel and the gradual automation of production, which led to a revision of the entire spectrum of specialties. Particular attention is paid to the notion of "information economy" and "labor market", their peculiarities and influence on the transformation of the role of human capital in society. The view is that the automation of production processes does not lead to the levelling of the role of employees at all, but rather to complicate work tasks and re-profiling of personnel in accordance with the new needs in the labour market. It is determined that in today's conditions the labour market has been transformed and stands mostly in the form of the human capital market. The dynamism of the service sector is shaped by the diverse professions of various 
fields of activity around the world. It is pointed out that the share of jobs requiring highly skilled personnel tends to increase in the spheres of business services and information technologies, especially in progressive countries. It is worth noting that in the service sector, especially in the retail trade, tourism and transport sectors, the level of employment is growing even on low-skilled human capital. The work efficiency improved due to access to high-speed Internet, which transformed the structure of work by providing constant access to information. The flexibility for both workers and employers became the result of such improvement. It is also noted that the labour resource in the classical sense gives the way to highly qualified human capital, as new vectors of the development of the information economy predict multitasking and flexibility of work processes. At the same time, the lack of reforms in Ukraine related to the transformation of the labour market, the creation of new professions and the legislative framework, which would contribute to the training of personnel, is indicated.

Keywords: information economy, human capital, knowledge economy, labour market.

У статті розглядається процес перетворення ринку прайі та ролі людського капіталу у ньому у зв'язку зі змінами, що відбуваються в Украӥні та світі. Збільшення кількості інформачії призвело до трансформаџії системних прочесів, переміщення векторів у підборі кадрів та поступової автоматизаиії виробництва, яке змусило переглянути увесь спектр робочих спечіальностей. Особливу увагу приділено поняттям «інформачійна економіка» та "ринок праці», їх особливостям та впливу на трансформаџію ролі людського капіталу в суспільстві. Розкрито думку про те, що автоматизація виробничих процесів призводить зовсім не до нівелювання ролі пращівників, а навпаки до ускладнення робочих задач та перепрофілювання персоналу у відповідності до нових потреб на ринку праці. Визначено, що в сучасних умовах ринок прачі трансформувався $і$ виступає здебільшого у формі ринку людського капіталу. Динамічність сектору послуг форматуе різноманітні професії різних сфер діяльності у всьому світі. Окреслено той факт, що частка робочих місиь, що потребує висококваліфікованих кадрів має тенденцію до зростання у сферах бізнес-послуг та інформаиійних технологій, особливо у прогресивних країнах. Не можна не відмітити, що у сфері послуг, особливо у роздрібній торгівлі, туристичній та транспортній сферах, зайнятість зростає навіть на низькокваліфікований людський капітал. Підвищення ефективності праиі відбулось за рахунок доступу до швидкісного інтернету, що поліпшило як структуру роботи, надавши постійний доступ до інформаиії, призвівщи до підвищення гнучкості роботи як прачівників, так і роботодавиів. Також зазначено, що трудовий ресурс y класичному розумінні поступається місием висококваліфікованому людському капіталу, тому що нові вектори розвитку інформаційної економіки передбачають мультизадачність та гнучкість робочих прочесів. Разом з тим, вказано на недостатність реформ в Украйні, пов'язаних з трансформачією ринку прачі, створенням нових професій та законодавчої бази, яка б сприяла підвищенню кваліфікації кадрів.

праці.

Ключові слова: інформаційна економіка, людський капітал, економіка знань, ринок

Introduction. The movement of employees into service and information sector indicates the series of continuous structural changes in the development of a post-industrial society. It affects the level of economic development, living standards of the population, quality, dynamics and type of economic growth.

In Ukraine, the process of transforming employment system and the role of human capital is spontaneous, requiring the creation of institutions for system control 
over the development of the information service sector, special incentive and regulatory mechanisms.

It is significant that the influence on the labour market is one of the keys in modern structure of the Ukrainian product in terms of world economic relations, as well as the creation of national income, as well as a qualitative solution to the question of restoration of indicators of the Ukrainian national economy as a whole.

The automation of the most producing processes gives not only the new way for the development of different scientific areas but also for creating a new kind of staff.

Theoretical and methodological approaches to the research in the employment sphere at various stages of the evolution of socio-economic systems are contained in the writings of the classics of the economic theory of K. Marx, J. Keynes, A. Marshall. The development of employment under the influence of information technology is considered in the works of foreign scientists such as G. Green, D. Brachchi, J. Smith, J. Hecker, R. Frimen, as well as domestic - Y. Tsizhma, A. Maslov, I. Malyk.

The actuality of the research and the choice of the topic is justified by the insufficient degree of disclosure of the prospects and methods of making changes in the role of human capital at the labour market of Ukraine.

Setting objectives. The purpose of the research is to identify the nature and transformation of the role of human capital in terms of the information economy. It includes the following tasks:

- to identify the features of the information economy;

- to discover the characteristics of the role of human capital in the labour market in the information economy, as well as the processes of automatization and state regulation.

Methodology. The methodological basis of the research is empirical and theoretical methods of knowledge of the surrounding economic reality. Empirical methods consist of gathering the facts, their grouping, taking into account all the changes that are associated with them. Theoretical methods are the means of penetration into the essence of the investigated economic phenomena, the disclosure of the laws of their development and functioning. The methods of comparison and grouping, inductive and deductive methods were also used.

Research results. It is significant that the development of the information economy is the main driving force of economic growth in the new information space. It is primarily connected with changes in the quality of human capital, the conditions for improving human potential as the main productive power of society, moving to the information stage. The centre of all transformations in the information society is the process of qualitative changes in the person itself. According to this, it has arisen the fourth main form of people's wealth. It is the level of intellectual and spiritual 
development, the massive carrier of which becomes a new personality - an engine of innovative economic growth.

The knowledge economy is defined as the next stage (phase) of the development of industrial society. It is a special type of economy in which welfare depends, in one hand, on knowledge-intensive assets - knowledge, experience, knowhow etc. On the other hand, the accumulation of industrial society economy is determined by material factors. The determination of the information society used different criteria such as technological, economic, labour, spatial, consumer and creative criteria.

According to the definition given by I. Malyk, the information economy is a type of economy where the productivity and competitiveness of business entities depend primarily on their ability to generate, process and effectively use knowledgebased information. Moreover, the information economy can be defined as an economy in which information is a type of currency and a product [4].

Having studied various definitions of the information economy by domestic scientists, we can give the following features of its formation.

Firstly, the emergence of new productive forces radically changed the material and technical base of production by bringing the automation, information resources and computer technology with a global Internet network.

Secondly, the information economy is characterized by the introduction of information technologies in production, trade and services, as well as the development of a computer network of the Internet, which is the basis for the creation of network enterprises and network intelligence.

Thirdly, the nature of labour in the information economy is changing, which led to the emergence of a new type of informational activity and new forms of labour, which are characterized by remoteness.

Fourthly, structural changes in the information economy occur at the macro and microeconomic levels. At the micro level, such a change means the emergence of a new type of enterprise, which operates on the Internet, uses separate functioning and territorially separate workers and has almost no tangible assets (virtual corporations). At the macro level there is a new branch of the economy - the information industry that arose as a result of the merger of branches of computer technology (computer production, software development, implementation of services for their maintenance), communications (Internet, telephone, cable television, radio, and information content (library, archive and publishing, information services, entertainment) [4].

Therefore, the essence of the labour market as a driving force, which is currently transforming through the influence of informatization and automation of society, manifests itself through performed functions of the socio-economic life of society functions; include informative, social, stimulating and regulating functions.

The labour market has a number of features that impose an imprint on its functioning and transformation. 
The first feature of the labour market is the inalienability of property rights for goods by its owner. Labour represents the process of spending its workforce. Although, there are special relationships in the process of buying and selling of the product.

The second feature is the long duration of contact between the seller and buyer's workforce. In the market of consumer goods and services, agreements are short-termed, while in the labour market they are long-lasting.

The third feature is that the labour market is allocated as an object of public administration with different combinations and the degree of use of political and administrative methods in all countries, regardless of the type of socioeconomic system in which they were formed.

The fourth feature is the high significance of the reliable aspects of the transaction in the typical market of mass material products for the buyer and seller. The basic agreement is the price and quality. In the labour market, the other indicators prevail, among which should be distinguished the following ones: content, conditions and operating principles; job security safeguards; the possibility of self-realization (social mobility); the psychological climate in the labour collective; transport accessibility of the workplace; moral satisfaction with work etc.

The fifth feature is the presence of a large number of institutional labour market structures. Legislation regulates the structure of participants in market relations. All of them should have the ability to make decisions and be responsible for the results and observing the established rules.

The sixth feature is the need to take into account the "human factor". The main figure in the labour market is a person. That is why we deal with the specific nature of this resource. Every person as the transmitter of the workforce has a set of physical, intellectual, cultural, national, religious and political qualities. These qualities impose a specific imprint on the functioning of the labour market.

The labour market in modern conditions increasingly serves as a market of human capital.

The service sector has exhibited the dynamism, encompassing a diverse range of jobs, across countries and regions. While highly skill-intensive service jobs such as computer systems design, finance and other business services have generally been on an increasing trend, their share in overall employment remains low, particularly in developing countries. A large part of employment growth in services has been in lowskill jobs, such as retail, travel or transport. Growing access to high-speed Internet has transformed the structure of work, given permanent access to information, improved connectivity and increased efficiency of business processes. This has suggested for greater job flexibility for both workers and employers [2].

It is believed that nowadays information technologies can make a decisive contribution to strengthening the relationship between productivity growth, output, 
investment and employment. New types of services spread across networks are able to create many work positions, which confirms the practice of recent years.

N.V.Lopatina marks the process of becoming an "innovative type of employment". In her opinion, this is the emergence of new professions that ensure the sustainable development of the information environment; the transformation of the established professional directions in accordance with prevailing information and social-information technologies [3].

The global nature of informatization generates new technologies, which, in turn, generate new professions. It is a permanent process. New trends in sociotechnological development cause the formation of new professional trends. The synthesis of already existing directions moves them to another substantive area. For example, the increase in the professional information space in the direction of intellectualization of information professions, which requires not only the intensive possession of technology but also increasing knowledge in the process of information work. The growth of the information component in the professional activities of representatives of leading industries causes the virtualization of individual professional areas. "Material" impact on the world, direct contacts with the environment, with direct industry resources inferior to a place in a number of manipulation areas at the information models of real things, the creation of parallel reality and system its relations with reality.

It is found that information technologies, on the one hand, eliminate part of work positions in some industries. On the other hand, they contribute to the creation of new jobs and modify their characteristics. At the same time, it is necessary to take into account the whole set of elements.

The studies of McKinsey Global Institute suggest that in both developed and developing countries, workers without higher education face with greater risks in area of job automation [1]. This result supports the notion that higher education helps develop skills and competencies that are useful to perform more complex tasks requiring advanced levels of perception as well as creative and social intelligencetasks that are considered difficult to automate.

Obviously, information and information technology has a long-term impact on the labour market, structurally changing the workforce, which nowadays is in high demand. We can highlight the main trends in the development of the labour market under the influence of information technology:

- the growth of the requirements for the educational level of the employed,

- the increase in the number of employees in the information sphere,

- the globalization of the labour market,

- the emergence of the new forms of employment.

While most analyses suggest that the new technologies will continue to benefit higher-skilled workers, the alternative way of development cannot be eliminated. In the same way, as it was in the first two technological revolutions, future automation 
could displace highly educated and skilled professionals. The robots may start replacing doctors, translators, editors, lawyers, architects, reporters and even programmers. If such projections materialize, they will replace manufacturing as the sector most affected by automation [2].

That is why nowadays there is the need in well-qualified flexible and educable staff that will operate and control the automation processes.

Effective functioning of the economy at the macro and micro level requires the greatest possible correspondence of the qualifications and knowledge of the employee with the requirements that he needs for the servicing of modern equipment. This is especially important in the information economy. The employer is ultimately interested in the qualifications of the employee, his ability to perform specific functions.

The transformation of the Ukrainian labour market into an adequate information economy requires the development of many traditional structures (labour exchanges, regional labour markets, etc.), and areas with objectives for the information economy (global markets for skilled professionals, middleware firms head-hunters).

Obviously, the information economy raises the requirements for the degree of computer literacy of the employed. There are such relatively new types of professional activities as computer design necessary for the implementation of ecommerce.

Demand for professional intermediaries decreases in the traditional sense. Although, the demand increases for intermediaries, who has the aims to help the buyer navigate in a huge stream of information and find the product with the least expenses.

As the complexity of the operations goes up, the requirements for hired workers are also changing. There is the need for high adaptability to changes and flexibility. Therefore, it requires more intensive training, designed to ease the worker switching to different types of activities in a changing socio-economic space, in other words, increasing the need for workers with diverse skills. The process of destandardization of work positions begins, which implies an increase of various occupations in the structure of the workforce. It is determined by the denial of the same type of production, which requires the same skills from the employed.

In recent years, the institution of mediators has become widespread for searching of well-trained staff. These are the so-called headhunting firms specializing in finding, recruiting, and selecting by order. The phenomenon of employment is the so-called remote work, or the virtualization of jobs.

However, nowadays the obvious transformations do not exist in public administration. They should take into account the natural phenomenon of the labour market and the overall structure of the formation of a national product. In particular, this is: 
- the backwardness of the education system and scientific paradigm, as well as the motivation of a large proportion of the population to receive the education that meets the market requirements, the obsolete educational programs and entire training directions, the lack of targeted support of profile universities - the creation of the personnel reserve;

- lack of retraining programs, despite the fact that such programs could bring significant profits to the state;

- $\quad$ low level of enforcement in the information area;

- inconsistent state policy on information development in Ukraine, insufficient support for profile associations and unions, undeveloped legal base of legal lobbying, lack of a mechanism for compulsory coordination of decisions with representatives of specialized business associations that impedes a constructive dialogue between the state and business, participation business associations in shaping and implementing industrial policy.

Conclusions. The bulk of available empirical studies focuses on the technological feasibility of automation, without assessing economic, legal, regulatory or socio-political barriers. Just because a job could be eliminated, does not mean it will be eliminated. In many cases, where automation is technologically feasible, it may not be economically optimal. Firms will weigh the benefits of new automation technologies (for example a lower wage bill or higher productivity) against their costs. The adoption of new technology requires absorptive capacity and can involve significant costs including for material, employee training and production shutdowns. With uncertainty about demand and the ability to recoup these costs, firms may be unwilling to incorporate labour-saving technology even if it has the potential to improve productivity. In terms of potential benefits, an important factor in a firm's decision-making process is the cost of labour. This partly explains why developing countries with abundant cheap labour have so far not been visibly affected by automation. The generally low level of wages in many developing countries, particularly in the service sector, will also help to stave off automation and job displacement going forward. There are also immense legal and regulatory issues that need to be addressed for automation technologies to have a more far-reaching impact. Finally, there are often powerful interest groups, including trade unions, that fight to protect some workers and industries against the negative effects of automation.

To sum up, the transformation of the role of human capital in Ukraine comes from the influence of the automation and informatization of society. At the same time, we cannot say that this process happens rapidly, as the process of retraining of personnel, creation of new specializations in the education field and the legislative base, connected with the labour market, only start following the world tendencies of the information economy. 


\section{References:}

[1] "A Future That Works: Automation, Employment, and Productivity.” McKinsey Global Institute (2017). Available at: http://www.mckinsey.com/global-themes/digital-disruption/ harnessingautomation-for-a-future-that-works

[2] Frontier issues: The impact of the technological revolution on labour markets and income distribution (2017). Available at: https://www.un.org/development/desa/dpad/wpcontent/uploads/sites/45/publication/2017_Aug_Frontier-Issues-1.pdf

[3] Lopatina N.V. Novye professii $v$ informacionnoj sfere: opyt analitiko-prognosticheskogo issledovaniya [New professions in the informational sphere: experience of analytical forecasting research]. Available at: http://www.fact.ru/www/arhiv9s 17.htm

[4] Malyk, I.P. (2013) Tendenciyi rozvytku informacijnoyi ekonomiky v Ukrayini [Trends in the development of the information economy in Ukraine]. The Bulletin of Easteuropean University of economics and management, Economics and Management, vol.1, pp. 25-34. Available at: http://nbuv.gov.ua/UJRN/Vsuem_2013_1_5

[5] Maslov, A. (2011) Etapy rozvytku teoriyi informacijnoyi ekonomiky` $v$ drugij polovy`ni XX - na pochatku XXI stolit [Stages of the development of the theory of information economy in the second half of the XX - early XXI centuries].The Bulletin of Taras Shevchenko National University of Kyiv, vol. 128. Available at: http://cyberleninka.ru/article/n/etapy-razvitiya-teorii-informatsionnoyekonomiki-vo-vtoroy-polovine-hh-v-nachale-hhi-stoletiy

[6] Maslov, A. (2011) Teoriya informacijnogo suspilstva yak metodologichna osnova teoriyi informacijnoyi ekonomiky [The theory of informational society as methodological basis of the theory of informational economics]. The Bulletin of Taras Shevchenko National University of Kyiv, vol. 123. Available at: http://cyberleninka.ru/article/n/teoriya-informatsiynogo-suspilstva-yakmetodologichna-osnova-teoriyi-informatsiynoyi-ekonomiki

[7] Thizhma, Yu. I. (2013). Struktura zanyatosti naseleniya v usloviyah demograficheskogo krizisa $v$ Ukraine [The structure of employment in the demographic crisis in Ukraine]. Available at: http://cyberleninka.ru/article/n/struktura-zanyatosti-naseleniya-v-usloviyah-demograficheskogokrizisa-v-ukraine

[8] Umanets, T.V., Kosmina, E.N. (2012) Obshcheukrainskie $i$ regionalnye izmereniya sovremennyh tendencij razvitiya rynka truda [General regional and regional measurements of modern trends in the development of the labor market]. Available at: http://cyberleninka.ru/article/n/obscheukrainskie-i-regionalnye-izmereniya-sovremennyh-tendentsiyrazvitiya-rynka-truda. 